\title{
Relational Work in Airbnb reviews
}

\author{
María de la O Hernández-López \\ Philology and Translation Department \\ Pablo de Olavide University \\ Ctra. Utrera, 1, 41013 Seville, Spain
}

\begin{abstract}
Peer-to-peer businesses such as Airbnb have recently given rise to new travel trends in which electronic word of mouth, in the form of online consumer reviews (OCRs, henceforth), is the main trust mechanism with a threefold purpose: to make informed decisions regarding accommodation, gain good reputation, and manage the relational component as continuity from the offline stage of the experience. In the light of the above, this study will analyse 120 reviews (60 positive and 60 negative) written by Airbnb travellers and linked to three different emotional orientations: delighted/satisfied, ambivalent/neutral, and dissatisfied/disappointed. Taking an illocutionary and stylistic domain perspective, the reviews will be examined to understand how users manage relational work (Watts 1989, Locher and Watts 2005, Locher 2006, Locher and Watts 2008), and to ascertain what is likely to be the 'norm' in this particular genre (i.e., OCRs) and for the particular Virtual Community of Practice (VCoP, henceforth) (i.e., guests and hosts interacting in Airbnb). The results show that being polite seems to be the norm (hence being politic), while being rude or offensive is the exception. The data also suggest that users tend to be politic/polite through very enthusiastic and friendly messages, while dissatisfaction and ambivalence are shown by means of a process of depersonalisation, with a tone based on formality and distancing from the host. Information is also obtained from what is not said, which creates the implicature of dissatisfaction. This seems to be implicitly understood by the members of this $\mathrm{VCoP}$, who seem to perceive sociability as pivotal to assess their experience.
\end{abstract}

Keywords: Online consumer reviews, Airbnb, relational work, politeness, impoliteness, face

\section{For citation:}

María de la O Hernández-López (2019). Relational work in Airbnb reviews. Russian Journal of Linguistics, 23 (4), 1088-1108. doi: 10.22363/2687-0088-2019-23-4-1088-1108. 


\title{
Работа над межличностными отношениями в отзывах на сайте Airbnb
}

\author{
Мария де ла О Эрнандес-Лопес \\ Университет Пабло де Олавиде, Севилья, Испания \\ Ctra. de Utrera, 1, 41013 Sevilla, Spain
}

\begin{abstract}
Аннотация
В последнее время на таких онлайн-площадках, как Airbnb, которые дали толчок новым туристическим тенденциям, онлайн-отзывы потребителей становятся основным механизмом доверия и имеют троякую цель: принятие обоснованных решений относительно размещения, приобретение хорошей репутации и управление межличностными отношениями как продолжение офлайнобщения. В свете вышесказанного в данном исследовании будут проанализированы 120 отзывов (60 положительных и 60 отрицательных), написанных путешественниками, воспользовавшимися сайтом Airbnb. Они передают три различных эмоциональных состояния: восхищение/удовлетворение, амбивалентность/нейтральность и неудовлетворение/разочарование. Акцент будет сделан на иллокутивном и стилистическом аспектах с целью понять, как ведется работа по выстраиванию отношений, или «реляционная работа» ('relational work') (Watts 1989, Locher \& Watts 2005, Locher 2006) и выяснить, что может быть «нормой» в этом конкретном жанре (электронном отзыве потребителей) и виртуальном сообществе (т.е. гости и хозяева отелей, общающиеся на сайте Airbnb). Результаты показывают, что нормой является вежливость, а грубость или оскорбление - это исключение. Полученные данные также свидетельствуют о том, что пользователи склонны проявлять вежливость посредством восторженных и очень дружелюбных сообщений, в то время как неудовлетворенность и амбивалентность проявляются имперсонифицированно, через официальный стиль и дистанцирование. Имплицитно информация о неудовлетворённости передается также через умолчание о тех или иных моментах. Представляется, что это понимают и члены данного сообщества, которые, по-видимому, воспринимают сообщение информации как необходимое условие оценки.
\end{abstract}

Ключевые слова: онлайн-отзывы потребителей, Airbnb, работа над межличностными отношениями, вежливость, невежливость, лицуо

\section{Для цитирования:}

María de la O Hernández-López (2019). Relational work in Airbnb reviews. Russian Journal of Linguistics, 23 (4), 1088-1108. doi: 10.22363/2687-0088-2019-23-4-1088-1108.

\section{Introduction}

Airbnb represents the most successful platform for accommodation sharing and experiences to date (Forbes 2018, Sundadarajan 2014), and is presumably the most popular platform for peer-to-peer accommodation in general. Its versatility (as it can be used as a communication tool with hosts, accommodation booking, search of experiences and posting of reviews, among others), popularity (established in many countries), social nature ${ }^{1}$, and the features of its review system (e.g. anonymity is not allowed, travellers are also evaluated, and there is user-friendly communication system that enables online interaction, among others) are characteristics that favour both its own success and trust

1 While it is true that many travellers renting apartments via Airbnb are not likely to meet the host (based on personal experience), travellers interested in meeting local people and attracted by the social appeal of this CoP usually decide to rent a private room at the host's house, so that offline, interpersonal contact is possible during their stay. This study only focuses on the latter. 
among users. However, while the business and marketing literature provides a great amount of information regarding this platform, studies regarding communication in Airbnb, as well as its review system from a pragmatic perspective are almost nonexistent (but see Bridges and Vásquez 2016 and Hernández-López 2019). This study aims to explore OCRs in Airbnb to bridge this gap.

Previous research has shown that, while OCRs as a genre have characteristics of their own, every social platform will also constitute a separate Community of Practice $\left(\mathrm{CoP}^{2}\right)$ (Eckert and McConnell-Ginet 1992, Mills 2003), or VCoP (Dubé et al. 2005) with features that are not transferable to other types of OCRs. The literature has already pointed out the differences between product-oriented and experiential OCRs (Vásquez 2011, 2014), as well as between business-to-peer and peer-to-peer travel patterns (Tussyadiah and Pesonen 2015). Airbnb has also been identified as a community of travellers with interest in both practical aspects of the experience (Guttentag et al. 2017) and socialising with locals in the target destination (Ert, Fleischer and Magen 2016). That said, we believe Airbnb must be studied as a separate CoP where travellers constantly interact in both the online and offline worlds, and whose review system is constrained by the sense of community ${ }^{3}$ its users have (Hernández-López 2019). It is precisely this social nature that makes Airbnb a platform of interest from a relational point of view, given that its review system has a threefold purpose: to make informed decisions regarding accommodation in a travel destination (guests), gain good reputation (both hosts and guests), and manage the relational component as continuity from the offline stage of the experience (both hosts and guests).

In the light of the above, this study will analyse 60 positive and 60 neutral and/or negative Airbnb reviews from an illocutionary and stylistic domain perspective. More specifically, this paper focuses on how Airbnb guests, who have shared some time and

${ }^{2}$ However, this CoP or VCoP is not among travellers themselves (who cannot interact via the platform) but among travellers and hosts. Despite this limitation, the notion of CoP is still relevant here in that the platform gathers individuals with similar interests, willing to share their knowledge about accommodation. Also, their interactions, both in the form of personal contact and OCRs, will have an impact on their knowledge and practice. It is through the process of sharing information and experiences with the group that members learn from each other, while they obtain information that will help them take decisions. VCoPs are usually found in the form of forums (Dubé et al. 2005). Airbnb provides the opportunity to post a review and answer to reviews that have been posted about each individual. See also footnote 3 for the notion of belonging in the platform.

${ }^{3}$ Due to the rapid growth of Airbnb since its foundation in 2008, its CEOs have made every effort to enhance the sense of community of this platform, as well as its users' sense of belonging. Apart from the versatility of the platform, which allows for communication among users (mainly guest-hosts), its advertising campaign enhances this sense of belonging ("belong anywhere") and has been labelled by business experts as a "global community", as in https:/www.thebrandingjournal.com/2014/07/ airbnbs-consistent-rebrand-focuses-sense-belonging-community/. Besides, hosts can also interact with each other in a related website (https://community.withairbnb.com), so that they can express their concerns and doubts, as well as explain their experiences via a public forum and private messages. So as to contribute to this sense of community, one of its CEOs, Brian Chesky (@bchesky) usually uses twitter to remind users that this is not an accommodation platform only to search a house, but a community of users with common interests seeking a home. 
space with hosts (i.e., who rented a room at the host's house), manage relational work (Watts 1989, Locher and Watts 2005, Locher 2006, Locher and Watts 2008) in positive reviews, vis-à-vis lukewarm and negative evaluations, so as to know what is likely to be the norm of appropriateness in each case, and how guests manage polite, politic and impolite messages addressed to the host and other readers. By adopting a genre approach to relational work (cf. Garcés-Conejos Blitvich 2010 for a genre approach to the study of im/politeness) and by looking at the intersection between genre and the features of this $\mathrm{CoP}$, we aim to understand how macro issues (e.g., previous contact, as mentioned in reviews) and micro issues of the interaction (e.g., wording in the reviews) will help ascertain what is the norm (i.e., expected, politic) and what is the exception in this review system.

This paper will be structured as follows: first, a literature review on Airbnb as a platform, an overview of politeness and OCRs, as well as relational work from a genre perspective, is provided. Next, the results, presented in three different subsections (1) delighted/satisfied users, 2) neutral or ambivalent users, and 3) dissatisfied users), and a related discussion about relational work, is provided. The paper closes with some conclusions.

\section{Airbnb as a peer-to-peer marketplace}

Airbnb belongs to the group of so-called peer-to-peer (P2P) marketplaces. Online P2P marketplaces refer to individuals (consumers) who interact directly with other users (sellers) who are non-employees, while the marketplace website is maintained by a third party (Botsman and Rogers 2011). Examples of P2P markets are eBay (online auction site) and Rent The Runaway (renting designer dresses), among many others. Within this group, those offering a particular service, rather than a product, are the most popular, in that users seek unique experiences in which social interaction is central (Ert, Fleischer and Magen 2016: 62). Some examples include food services (Eatwith, VoulezVousDiner), taxi services (Uber, BlaBlaCar), and accommodation services (CouchSurf, Airbnb, Vayable, Love Home Swap). This group of P2P markets has also been identified as collaborative consumption (Pizam 2014: 118), and its main trust mechanism is known as experiential OCRs (Vásquez 2011, 2014).

Airbnb defines itself as "a social website that connects people who have space to spare with those who are looking for a place to stay", with special emphasis on those interested in having a "personal, meaningful experience" (Airbnb website). Indeed, Airbnb's emphasis on its social appeal (Ert, Fleischer and Magen 2016) implies creating networks as a form of social capital (Burt 2000, Wong and Salaff 1998) in a system in which their members trade with a personal commodity: their living spaces. In this sense, each member's network capital is based on trust in others and self-built reputation (Rosen et al. 2011), with a twofold function: more opportunities to host other travellers and the construction of a sense of community within this network.

In line with social networks, each member creates a personal profile including age, gender, location, education, and any other personal details that they may want to let others know. Members may choose to be either host or guest, although combining both 
roles in the same profile is also possible. This fact is key to understanding the complexity of this dynamic system, as each member may be evaluated as a host (similar to businessto-peer platforms), but also as a guest. Guests will be allowed to read their host's review (and vice versa) on condition that they post their own review about the host. Thus, this system ensures that their opinions are not biased by the other parties' comments.

In line with business-to-peer platforms (B2P) such as TripAdvisor, guests use, on the one hand, star ratings to evaluate features of their listings (i.e. their properties), and experience (mainly cleanliness, location, veracity and communication), together with the written texts used to share their experience. However, personal interaction and the fact that the Airbnb experience is built among peers (and not between businesses and peers), make this platform have characteristics of its own, mainly because it is not only the room or apartment to rent that matters, but also personal interaction (Bridges and Vásquez 2016, Cansoy and Schor 2016), and it is precisely this personal interaction in the offline component of the experience that may have an impact on reviews.

\section{Politeness, the genre of OCRs, and travellers' websites as VCoP}

The emergence of online sites for communication, business and leisure has marked a shift from situated politeness to globalized politeness, in which it is the affordances of the system, together with culture and other sociological variables, that have an impact on interaction. Such is the case in OCRs; overall, they have been studied as a genre to understand how users manage face, politeness and other relational issues. A case in point is Vásquez $(2011,2014)$, who found that complaints in TripAdvisor are rather different from face-to-face complaints, in that prosumers (i.e., consumers who are also producers of online content) attempt to maintain public self-image or social identity, rather than the other's face. This is partly given by the system, as the experience under review is usually based on an institution (e.g., a hotel). Ho (2017) also studied experiential OCRs from the angle of the reviewed institution to understand how managers respond to complaints, with attempts to recover face and enhance rapport.

In the sharing economy business, Dayter and Rüdiger examined users' complaints in CouchSurfing and found that conflictive reviews are expressed in a way that balances "the obligation to write honest references" with "the desire to protect face" (2014: 194). The accumulation of social capital is also a motivation to avoid blunt criticism. Therefore, even when the complaint is obvious, the insertion of positive elements helps ensure both positive self-presentation and the reaffirmation of solidarity with the addressee (p. 207). In line with this, Bridges and Vásquez (2016) use the term "lukewarm" review to designate those evaluations that are not explicitly negative but cannot be classified as positive either, and explain the reasons for this positivity bias in Airbnb (host-guest social interaction or personal acquaintance, the reciprocity of the review system, the sense of mutual trust on this online community and lack of anonymity, which means that every contribution to the website is also a contribution to building host and guest identities).

One of the latest contributions to this area of research is Hernández-López (2019), who examined positive Airbnb reviews written by British speakers. The author found that 1) reviews in this platform have characteristics of their own, such as reciprocity, 
considering the host as part of the experience, importance given to the host's personal traits and identity, etc. 2) personal acquaintance with the service provider has an impact on the way reviewers write their evaluations, and 3) these reviews are, in fact, social reviews in that users take the opportunity to not only inform other readers but also contact the host and ensure a certain continuity in terms of the relationship established during the offline component of the experience.

The above-mentioned studies reveal two facts: 1) that the review genre is not homogeneous across platforms; and 2) that the affordances of the website, together with the pragmatic affordances (Virtanen 2017) of the review system constrain relational considerations (e.g. politeness, rapport, etc.). It is at this point that we see that, while genre (i.e., text genre) has been advocated as a useful unit of analysis in politeness studies (cf. Garcés-Conejos Blitvich 2010, Garcés-Conejos Blitvich and Sifianou 2019), the specific profile of each $\mathrm{CoP}$ must be taken into account as well. For the purpose of this study, therefore, the features of Airbnb as a CoP will be taken into account to understand its review system as a genre. The CoP found in Airbnb is that of a community of travellers and hosts with a sense of belonging ${ }^{4}$, where guests, or travellers, are interested in accommodation offered by local people or peers, and are often attracted by the system's social appeal (Hernández-López 2019). Hosts, in turn, often show interest in offering accommodation with differentiating characteristics (e.g., unique experience, low price, very friendly hosts, or great location, among others). This review system, as a genre, involves mutual evaluations (guest and host), and is addressed to both a wider audience (i.e., other travellers) and the person that is being evaluated, be it the host or the guest. Users are not kept in anonymity and strive to gain good reputation in order to be shown as trustworthy and gain more users. It is by looking at the intersection of this $\mathrm{CoP}$ and this review system as a genre that relational considerations will be examined.

\section{A genre approach to relational work}

The abovementioned studies show that, while OCRs are not a new field of study in politeness studies, its paths of research are scarce and, in the case of peer-to-peer consumption, almost non-existent. In the case of Airbnb, given its social nature (Hernández-López 2019, Sthapit and Jiménes-Barreto 2019), we contend that a model within interpersonal communication that is wide enough to cover the versatility of the online milieu is needed. In this sense, politeness will be understood as

a fundamentally discursive concept, that is, one which does not have an objective existence outside of the discourses in which it is oriented to or talked about by users and observers of (different varieties of) a language. (Haugh 2019: 201)

Something that can be deducted with certainty from this definition is that politeness is shaped in the ongoing dynamics of interaction, in line with the so-called 'third wave of politeness studies' (Garcés-Conejos Blitvich and Sifianou 2019). This third wave

\footnotetext{
${ }^{4}$ On the sociability of Airbnb, see footnote 3.
} 
includes approaches such as Arundale's $(1999,2006)$ face constitution, SpencerOatey's $(2000,2008)$ rapport management, or Watts' (1989) relational work (see also Locher and Watts 2005, Watts 2005, Locher 2006). Despite their differences in scope and approach, all of them consider that politeness is not an ever-present phenomenon but is given in specific situations, and that interlocutors need not be interested in being polite only. Thus, while rapport management (Spencer-Oatey 2008) acknowledges that there are at least four rapport orientations (rapport enhancement, rapport maintenance, rapport neglect and rapport challenge), relational work (Watts 1989, Locher and Watts 2005, Watts 2005, Locher 2006) also aims to cover the entire spectrum of interpersonal behaviour, from negatively marked behaviour (i.e., impoliteness or rudeness), via non-marked or politic behaviour, which involves being appropriate to the interaction in question, to positively marked behaviour (i.e., politeness) (Locher 2006: 250). Thus, depending on the interlocutors' intention, they may engage in face-enhancing, face-maintaining and face-aggravating relational work (Locher and Watts 2008, Angouri and Locher 2012).

Relational work is defined as "'the work' individuals invest in negotiating relationships with others" (Locher and Watts 2005: 10) and acknowledges that most of the time it is the unmarked form, rather than politeness or impoliteness, that is expressed and perceived in interaction. Also, appropriateness in interaction is subject to the specificities of the context in question. Thus, participants familiar with a particular CoP invest in appropriate degrees of relational work and are likely to share what they deem appropriate locally, at the same time as constantly negotiating what is and what is not appropriate, what is polite, impolite or over-polite ${ }^{5}$. While it is true that negotiation is not something new when it comes to research on politeness or the relational component in general (cf. Fraser 1990), what constitutes a fundamental shift of perspective is that much of the relational work will be assessed as non-marked ('appropriate' or just 'normal', a lay person may say), or behaviour that participants construct as being "appropriate to the ongoing social interaction" (Watts 2003: 276). Within this discursive approach (Locher 2006, but also Garcés-Conejos Blitivich and Sifianou 2019, among others), the researchers' main task should be to identify what is appropriate and the expected norm, while what is polite or impolite is also subject to participants' evaluations. This perspective is inclusive, given that politeness may include a variety of styles based on intentions and linked to speech style, such as friendliness, distance, respect, modesty, individuality or solidarity, to name a few (cf. for instance, Barros García and Terkourafi 2014, for a discussion regarding rapprochement and distancing contexts).

${ }^{5}$ Hernández-López and Fernández-Amaya (2019) also include the category 'very polite', as different from 'polite'. They requested a number of participants to rate their hotel experience as 'very polite', 'polite', 'neutral' or 'impolite', and explain why. The findings revealed that, while 'very polite' is linked to behaviour that goes beyond the travellers' expectations, 'polite' was marked when communication matched their (high) expectations and where interaction was considered appropriate. The category 'neutral' was associated with indifference, and impoliteness with a bad hotel service in general. 


\section{Methodology}

\subsection{Data}

The data of this study consist of a sample of 120 Airbnb reviews: 60 reviews with a positive valence (i.e., experiences that have been depicted in positive terms) and 60 reviews with a negative valence (i.e., reviews in which there is at least one negative comment).

The selection of the corpus responds to a series of criteria:

1. Any destination within the UK.

2. Any review written in English.

3. Travellers staying in a private room for two people at the host's house. This option has been selected because we understand that it gives more opportunities to interact with the host(s) than those cases in which whole apartments are rented. It is assumed that sharing some time and space with hosts will potentially give more opportunities to engage in interpersonal communication that may have an impact on the final write-up of the review.

4. Only experienced users (i.e, those with more than five reviews) were considered to ensure that they are knowledgeable of the underlying norms of behaviour of this $\mathrm{CoP}$, and familiarized with the review genre. As expressed by Locher (2006: 253),

interactants participating in the same speech event and being familiar with the norms of behavior established in this particular type of interaction over time will of course be more likely to have approximate evaluations than interactants who are newcomers to a particular community.

Finding positive reviews is easy in Airbnb, given that more than $90 \%$ belong to very satisfied users (cf. Bulchand-Gidumal and Melián González 2019). In this sense, and after considering the abovementioned selection criteria, the 60 positive reviews were selected randomly out of an initial selection of 230 positive reviews of accommodation in Bristol. In turn, and given the difficulty to find neutral/negative reviews in one single destination, the selection of this second group was not random, but the result of detailed reading of reviews at different destinations (Glasgow, Bristol, London, Edinburgh, Birmingham, Lancaster and Belfast). Those reviews that described any type of fault, disagreement, criticism or ambiguity were collected as part of this data set. At times, some reviews are ambivalent in meaning but include the reply of disappointed hosts. In these cases, we understand that the review has a negative valence as well. Regarding ethical considerations, all the reviews are open access in the platform. Examples in this paper have been anonymized.

\subsection{Procedure}

The analysis of the data will be based on the computer-mediated discourse analysis (CMDA) perspective proposed by Herring (2004: 339), "grounded in empirical, textual observations" and "informed by a linguistics perspective". More specifically, data will be examined considering an illocutionary (i.e., the performance of certain speech acts) and stylistic (e.g. choice of tone or choice of genre-bound lexis) domain perspective to understand how travellers manage relational work.

Data will be organised attending to the users' emotional stance: (1) delighted or satisfied, (2) lukewarm or ambivalent, and (3) (very) dissatisfied. Whereas (1) and (3) 
will be reviews that are unequivocally positive or negative, (2) includes reviews that either mix positive and negative comments, or are ambiguous in tone and/or intention. In all three cases, the role of content, specific speech acts and tone, for instance, will be examined to determine the type of relational work reflected in reviews. Thus, this analysis will hopefully contribute to understand what constitutes appropriate or politic behaviour in this particular genre (experiential reviews) and $\mathrm{CoP}$ (travellers in the sharing economy).

Given that we do not always count on the addressee's replies (i.e., they are optional) and the interpretation of other readers, we are aware of the fact that it may be difficult to differentiate between lukewarm and negative reviews. For this reason, we consider that reviews have a negative valence when there is at least one negative comment or note of dispraise in the review (even when the rest of the information in it is positive). Within this group, lukewarm reviews are those that are ambivalent in tone and wording, or those with compensation strategies to minimize the expressed fault (e.g., "It was very noisy but [the host] was super friendly and understanding, and we would give it a second chance"). Clearly negative reviews are those with scarce mitigation or clear disappointment, as in "Not clean at all. I wouldn't recommend". We will consider that reviews have a positive valence when these are unequivocally positive, and their users' emotional stance is that of clear satisfaction, as in the following review: "The property was beautiful and I really felt the luxury of a top hotel. The hosts made every effort to print a map, knowing where I was going to meet friends later. Really kind. Thanks for a great stay. I would definitely book it again".

Following Locher (2006), we will deem a message as polite when there is "positive concern for the addressee" (251), and a message will be impolite when there is lack of concern for the addressee's face or reputation, or when there is the desire of the speaker to attack face or clearly damage the host's reputation. In order to classify reviews, the host's reply (if there is any) will also be taken into account to understand how the review has been interpreted. Besides, the sample was coded twice in order to ensure validity of these classifications.

\section{Results}

The vast majority of reviews present features that orient towards enhancing the relational component. Overall, users not only aim to express what they think but also try to not damage the relationship at hand (either by enhancing it or by avoiding damaging it). Besides, there are a number of reviews that shows dissatisfaction and scarce concern for the other's face. This group, which constitutes a minority, is oriented towards aggravating the relational component. Table 1 below summarizes the findings in numbers.

Table 1

Classification of reviews according to the users' emotional orientation (delighted/satisfied, neutral/moderately satisfied and dissatisfied/disappointed)

\begin{tabular}{|c|c|c|c|c|}
\hline Data sets & $\begin{array}{c}\text { Reviews with a posi- } \\
\text { tive valence (60) }\end{array}$ & \multicolumn{3}{|c|}{ Reviews with a negative valence (60) } \\
\hline $\begin{array}{c}\text { Emotional } \\
\text { orientation }\end{array}$ & $\begin{array}{c}\text { Delighted/ } \\
\text { satisfied }\end{array}$ & $\begin{array}{c}\text { Lukewarm/ } \\
\text { ambivalent }\end{array}$ & $\begin{array}{c}\text { Dissatisfied/ } \\
\text { disappointed }\end{array}$ & Other* \\
\hline Number of reviews & 60 & 36 & 23 & 1 \\
\hline
\end{tabular}

*There was one review that did not seem to fit any of these categories. Due to space constraints, this 'other' category will be left out. 
In what follows, the different types of reviews will be examined, attending to the users' emotional orientation (delighted/satisfied, neutral/ambivalent or dissatisfied). A number of reviews will be presented to illustrate the features of language in each of the groups presented in Table 1 . The analysis will take a stylistic and illocutionary perspective to understand how this has an impact on relational work.

\subsection{Delighted and satisfied users}

Airbnb has been characterised by its positivity bias (e.g., Bulchand-Gidumal and Melián-González 2019), in which almost everyone seems to be satisfied, and even delighted $^{6}$ with the Airbnb experience. Within this group, reviews are a good opportunity to enhance the relational work built with the host, inform a wide readership of potential travellers belonging to the same community and enhance self-face and reputation as ideal traveller. Also, the tone and intention of this group of reviews seem to be influenced by the presence of the host as main reader, given that the style echoes face-to-face interaction at times. Below, Review 1 and Review 2 are illustrative of this group of reviews:

\section{Review 1}

$[\text { The host }]^{7}$ runs the best air BnB you could wish for — comfortable, stylish, great proximity to the city centre. It's better than most five star hotels we've been to! Sarah went above and beyond what we expected with the additional touches of drinks, snacks, toiletries \& breakfast. Our stay in Brighton was totally made by how brilliant this air BnB was. We can't thank you enough or wait to stay again!

\section{Review 2}

'Wow' pretty much says it all!!!! [The hosts] are really lovely and couldn't be more perfect hosts. We arrived to tea/coffee $\&$ biscuits and maps and listings (restaurants/pubs/shops etc). The apartment is really beautiful and spotlessly clean, even with the 2 adorable cats $\&$ dog! :- The room is lovely with the most comfortable bed I have ever slept in. I can't rate this highly enough - if you stay here you will be thrilled! (;)

As can be seen in these reviews, from a stylistic and illocutionary domain perspective, this group of reviews includes constant hyperbolic language (such as "It's better than most five star hotels" or "Sarah went above and beyond what we expected"), extreme adjectives (such as "brilliant"), exclamation marks, positive emoticons, informal language (such as "wow"), and a number of expressive speech acts such as constant praise (e.g. "[the hosts] are really lovely" or "you will be thrilled!"), enthusiastic "thank yous', wishes to come back ("we can't thank you enough or wait to stay again!"), and direct recommendations ("I can't rate this highly enough — if you stay here you will be thrilled! (;)"). Also, there are constant signs of emotional language (e.g., "wow") embedded in personal narrative. All the reviews in this group of positive evaluations include at least three of these characteristics, which point towards personalisation (by naming

${ }^{6}$ The hospitality and marketing literature differentiates between 'customer satisfaction' and 'customer delight', which refer to different degrees of satisfaction or happiness (cf. for example, Torres and Kline 2013).

${ }^{7}$ As indicated in the methodology section, the reviews have been anonymized. "The host" will refer to the hidden name of the host. 
the host, or using 'you', for instance), as if they were semi-letters that show awareness of the readership (host and other users), denote that the host-guest relationship was positive and that there is the willingness to enhance the relational component and the host's face by means of this constant praise. This personalisation is common (to varying degrees) in the 60 positive reviews found.

These features are linked to a specific attitude and intention, and a type of relational work that may well be termed as 'enthusiastic friendliness'. In this sense, the way to show that the experience was very positive is through communicative involvement and informality, so as to leave clear that the experience was truly positive. By adding enthusiasm to the written message, users express their emotional orientation (i.e., their degree of (dis)satisfaction) and show that their message is reliable ${ }^{8}$. This constant friendliness and closeness has not been pointed out as typical in research on platforms of similar nature (e.g., TripAdvisor).

\subsection{Lukewarm or ambiguous reviews}

Within this group, comprising 36 reviews, there are two differentiated sets: those that are apparently neutral or not very enthusiastic in tone (11 in total), and those that include information about faults, but users invest much effort in expressing that it was something minimal or that other aspects of the experience were very positive, instead ( 25 in total). What these two groups have in common is that they cannot be classed as either positive or negative in essence. They are likely to leave a similar impression on the reader: that the experience was somehow improvable.

\subsubsection{Reviews with neutral comments}

Something to note here is that, given the readers' interest in reading other reviews (i.e., finding successful experiences), anything that is not very positive may be interpreted as negative. In other words, readers in this $\mathrm{CoP}$ are likely to seek very positive reviews as guides to know which options are better for them, in a way that something that is not 'excellent' or 'very good' is likely to be improvable. This shows the review system's sensitivity to "attribute framing" (Levin et al. 1998, Kamoen et al. 2015). Attribute framing refers to a cognitive bias in which the brain makes interpretative decisions depending on whether the information is presented in either positive or negative terms. Thus, while 'good' and 'not bad' are semantically equivalent, in this CoP, 'not bad' creates the implicature that a) there was something that actually went wrong, or b) the experience was not so positive to be expressed in more enthusiastic, unequivocally positive terms. Thus, lack of enthusiasm or further explanations imply the perception that something negative happened. This was found in 11 reviews in our corpus. In sum, neutrality is semantic (i.e., the wording is neither too positive nor too negative). However, from a pragmatic point of view, these reviews are not likely to be understood as neutral

${ }^{8}$ It is worth remembering that the main trust mechanism in Airbnb is precisely the writing up of references, and therefore, they must sound reliable and honest in order to be useful (Rosen et al. 2011). 
but as negative. In other words, enthusiasm implies that the experience is worth it, while lack of enthusiasm may imply that something went wrong. Review 3 and review 4 illustrate this group of reviews:

\section{Review 3}

OK place. The location is in walking distance to central Belfast. The house is fine, and we had no problems. We had to share a key with other guests whilst we were there but this was only temporary. [The host] wasn't there, but shared instructions for how to get into the flat and was contactable by phone.

\section{Review 4}

Room was big and clean. [The host] greeted us on arrival and showed us all we needed to know. Good place to stay if you just want a base to do your own thing.

Again, the stylistic domain may explain the emotional orientation of the user (i.e., lukewarm or ambivalent). To start with, this lack of enthusiasm denotes that users did not have the best of experiences. They also reveal that the relationship with the host was brief, disappointing or non-existent. Review 3, in particular, is very meaningful and illustrative of this seemingly neutral tone: the experience was not wonderful, but "OK", the house was not excellent, but "fine", and there were two aspects of the experience that were improvable (sharing the key and absence of the host). While it is not something that the guest may have expected, he acknowledges that the key sharing was temporary and that the host was easy to contact.

In review 4 there is a mixture of personalisation (as in "[The host] greeted us") and distancing from the host (as in "room was big and clean"). Here, relational work seems to be oriented towards neutrality in tone as well. In contrast to the previous group, these are depersonalised, with a special focus on the accommodation (and not the host). The lack of expressive speech acts (wishes, recommending, thanking, etc.) and the implicature created with the inclusion of 'just' in "if you just want a base to do your own thing" also informs readers of this lukewarm tone, so that what is not said (e.g., this place is not perfect if you expect constant sociability or and outstanding place) creates the implicature that the experience is improvable.

\subsubsection{Dispraise with mitigation}

In line with those reviews that show semantic neutrality, there are 25 reviews in the corpus under analysis that present mixed features: fault is addressed, mentioned or somehow expressed, but users, at the same time, invest time and effort in mitigating the information provided and expressing that other aspects of the experience went as expected. In this sense, this group of reviews shows a clearer awareness of the importance of relational work, despite one-time dispraise. Review 5 and review 6 illustrate this group:

\section{Review 5}

Listing is accurate. Kitchen was a bit small and toilet had some troubles, but [the host] was helpful. The location was good and the listing affordable.

\section{Review 6}

The apartment was good just as seen in the pictures, but not as clean as expected. There were no towels for us and it took some time until we got them. I think we maybe had bad luck because after we left everything was cleaned up and taken care of. The check-in and 
out times were really flexible and especially the [SENSITIVE CONTENTS HIDDEN] ${ }^{9}$ were really friendly and helpful. It was quiet although the underground station is very close and you can get around quick to central London. All in all I would recommend the apartment because I think we just had bad luck with the circumstances and I would give it a chance again.

Response from [the host]:

I am very sorry to read that. As I was out of town for 3 weeks and therefore throughout your stay, I couldn't make sure that my high standard were followed as usual. I do hope that your holiday in London was not spoiled by these circumstances, thus do not hesitate to contact me in future, I will make sure your stay will be as great as it will ever be.

In line with the reviews that show semantic neutrality, this group of reviews shows a displacement of focus from the host to the experience in general (i.e., objectification of the experience), on the one hand, and with an attempt to mitigate fault by means of a sandwiched structure (i.e., alternating praise that enhances or saves face, dispraise that points towards the fault, and praise that shows some compensation for what has been said). This can be seen in review 5, where the guest explains that the toilet had some kind of fault, but "[The host] was very helpful". Justifying fault, as in review 6 ("we just had bad luck"), among other relational strategies, shows the high awareness of the users being read by the host, but, at the same time, the need to be honest in this CoP. In this sense, mitigating fault sometimes includes features found in positive reviews, such as recommending or wishes to come back, among others. However, and as corroborated by the host's reply in review 6 , the review cannot be considered as positive, given the lack of enthusiasm and the complaint regarding cleanliness. From a relational work perspective, there is a tendency towards formalisation of the relationship, achieved by means of depersonalisation (i.e., not focusing on the person), objectification of the experience, and the use of more formal language (i.e., avoidance of friendly terms, as in positive reviews), with gradable adjectives and focus on descriptions, rather than emotions. Absence of the speech acts found in the previous group (thanking, wishes, recommending), as well as absence of emoticons ${ }^{10}$ are also a feature of this group of reviews. The effect that is achieved is that the writer is, to say the least, not delighted.

In sum, these neutral reviews (semantically speaking) may create the implicature of negativity from a pragmatic viewpoint. This is so, mostly, because Airbnb is a review system in which satisfaction is expected to be expressed in very positive terms, with displays of the emotional orientation of the user and unequivocally positive messages addressed to both the host and other users. Also, and in line with Vasquez (2011), users may not want to appear as 'moaners', given that their reviews also contribute to building their own identity and reputation in the website. Not addressing the host, directing the focus of attention to features of the accommodation instead of the host, or justifying fault

9 Capitalised phrase added by Airbnb.

10 According to Chairunnisa and Benedictus (2017: 124) in their study on WhatsApp, users with negative emotions usually refrain from making an emoticon that shows their present emotion. 
may create the implicature that the user is trying to communicate something else. Therefore, in terms of relational work, adopting a neutral tone is by no means related to being politic, first because neutrality involves negativity in the Airbnb context, and second, because the hosts, to whom these comments are addressed, do not seem very satisfied with the comment posted (see review 6) and may even feel that their reputation is being damaged.

\subsection{Dissatisfied Users}

This group of reviews is characterised by the unequivocally negative tone and intention of their contents (i.e., expressing that the experience was dissatisfactory). In the data set under examination, 23 examples were found. Review 7 and review 8 illustrate this group:

\section{Review 7}

The room was unclean. We found used towels in bathroom, that was full of hairs. Nobody show up during our stay. For 79 euros we expected at least a clean place to sleep. We escaped early in the morning with more questions than satisfaction.

Response from [the host]:

I'm amazed!!! Firstly the house was clean for your stay like it is left for all the guests. When I'm not there myself I check with the housekeeper daily to ensure the bed, towels and room are clean and ready for the purpose. Please read their reviews of praise for the cleanliness!! The price is not 79 euros, it is 47 pounds, which converts to 67 ... were you at the correct house? I messaged you twice during your stay I got no reply. Regards, [the host].

\section{Review 8}

The room is not an ensuite. The flat is very loud and there's a constant coming and going of people until very late at night ( 2 am in the morning). The flat is kept in extremely unhygienic conditions. I felt quite unsafe during my stay.

Response from [the host]:

The room was an (URL HIDDEN) ${ }^{11}$ and the flat is very safe. I offered this woman everything and she said no. I offered to cook breakfast she said no. I didn't give you the keys because I didn't feel safe myself and I wanted to know when you cam in and out. I have a lot of reviews from other guest that says otherwise. I think if you have a lot of phobias u should stay away from Airbnb and book a hotel. If you don't like people stay from Airbnb. I had only a friend in the flat that came to visit and we were just watching tv. I think you are a paranoid and all what you said was absolutely bogus. I wish I didn't meet you anymore.

As can be seen in the two reviews used as an illustration of this group, users prefer to write in a more depersonalised, objectified style ("the room was unclean", "nobody show up"), with no mention of the host directly, and a tendency towards formality (e.g. passive voice), rather than informality (e.g., "Wow!", in review 2), with descriptive accounts of what went wrong (and no mention of positive aspects of the experience).

11 Information hidden by Airbnb. 
There is clear distancing from the host, as in "nobody show up", or "The flat is kept in extremely unhygienic conditions", with attempts to show objectivity in the guest's descriptions. As with very positive reviews, from a stylistic point of view there is a preference for extreme adjectives and adverbs, this time to show the negative side of the experience (e.g., "extremely unhygienic"). According to Edwards (2000), the use of these 'extreme case formulations' is motivated by particular intentions by the speaker, such as commitment and certainty. In the case of the data set examined, the intentionality behind these extreme case formulations may be communicating trust in what is being said, as well as leaving clear that the message is unequivocally negative (in this group of reviews) or positive (in the case of the first group analysed).

Besides, the use of exclamation marks is common in this group of reviews (in both guests' and hosts' reviews) in order to emphasize anger, disappointment or frustration. While positive reviews included details of how wonderful the experience was, this type of reviews tends to be shorter in form, focused on fault, rather than on the host, and with no mitigation. Clearly, the relationship with the host did not seem to go as well as expected. This supports previous findings that reveal that, when the relationship with the host is not good, the experience overall is rated as bad in Airbnb (cf. Sthapit and Jiménez-Barreto 2019). Besides, showing frustration was common here, as can be seen in the wording and tone (e.g. "I felt quite unsafe"). The absence of speech acts that are common in very satisfactory experiences (e.g., signs of gratefulness) also shows how little attention is paid to relational concerns when drafting the reviews in this group. Regarding face concerns, reviewers may have a twofold intention: they have written comments that are face-aggravating towards the host, and they warn other fellow travellers. Thus, they seem to be engaging in relational work with the other travellers (at least indirectly).

\section{Relational work in Airbnb reviews: discussion}

Overall, the findings suggest that users tend to enhance the relational component in Airbnb reviews mainly by showing friendliness and enthusiasm and by presenting their experience as highly emotional. This is likely to occur in the vast majority of reviews overall, as more than $90 \%$ of the reviews in this system are positive (cf. for example, Bridges and Vásquez 2016, Bulchand-Gidumal and Melián-González 2019). The features found to express positivity were common in all 60 reviews under examination (e.g., hyperbolic language, host-addressing, signs of gratefulness, constant praise, friendliness, etc.). This points to the idea that what seems to be the norm in the system is to be publicly and ostensively face-enhancing through effusive friendliness and informality. In this sense, being polite with the host is also being politic (i.e., as expected), and the way to be polite/politic is by means of displays of friendship, closeness, solidarity and informality.

In contrast, those reviews with a negative bias were of three types: those expressed in a neutral, lukewarm tone, those that included some dispraise combined with praise or positive comments, and those that involve face attack and were clearly negative. 
The analysis showed that semantically neutral reviews are by no means related to being politic. As expressed in the results section, semantic neutrality creates the implicature of pragmatic rudeness, and this idea is reinforced by the host's reply (whenever there was any), usually offended by this seemingly neutral (and unfair?) evaluation. Interestingly enough, the way to express dissatisfaction to different degrees is by means of formality and distancing from the host, in a way that, while polite/politic behaviour in positive reviews is built on the basis of an effusive and friendly tone, impolite behaviour (if it can be considered impolite) is characterised by being formal, depersonalised and distant. Hence, respectful distance (a tone that is opposite to the one used in positive reviews) communicates dissatisfaction in this VCoP, and may be interpreted as face-aggravating towards the host. Other readers, however, may find it useful, given that negative reviews give them valuable information not only to help them take decisions, but also about the reviewer, who may have felt the moral obligation to be honest to other travellers.

This is revealing in that the dichotomy closeness-distance, or friendliness (which implies informality)-formality (which implies distancing from the addressee) needs not refer to two poles of politeness, but two different attitudes. Given that friendliness is the expected norm in this VCoP, moving away from said friendliness creates the implicature that the experience did not run smoothly. Lack of compensation strategies, but also lack of illocutionary enhancers such as 'thank you', illustrates how users neglect the relational component in order to show their frustration, for instance, in the face of what they had experienced. It is in this group of reviews that users try to save their own face (by demonstrating credibility, for instance), while the others' face is either disregarded or attacked.

Finally, those reviews that are ambivalent (i.e., those expressing fault but with mitigation and compensation strategies) seem to respond to two purposes: being honest with the other members in the same $\mathrm{CoP}$ and trying not to damage the relational component with the host in a way that more relational work is needed. Guests seem to engage in face-maintaining or face-enhancing relational work. These are cases in which the relationship was not bad, but users felt the moral obligation of expressing that there were some minor faults. Again, users wanted to express dissatisfaction while being politic and polite, in a way that self and other face are saved.

Something that these findings suggest is that, in a global environment such as Airbnb, the dichotomies closeness-distance and involvement-independence, are not only cultural orientations necessarily, as stated in previous studies (cf., e.g., Barros García and Terkourafi 2014), but are also subject to the users' milieu. Thus, each orientation will serve specific purposes: friendliness would be at the polite/politic end, while formality would be at the impolite, or face-aggravating, end of the continuum. In this sense, the tone and style of the reviews are likely to be the continuation of the relational work established during the offline stage of the experience. As a VCoP, the relationship comes first, and this is reflected in the positivity bias of these reviews as a genre.

The above-mentioned ideas are summarized in Figure 1. 


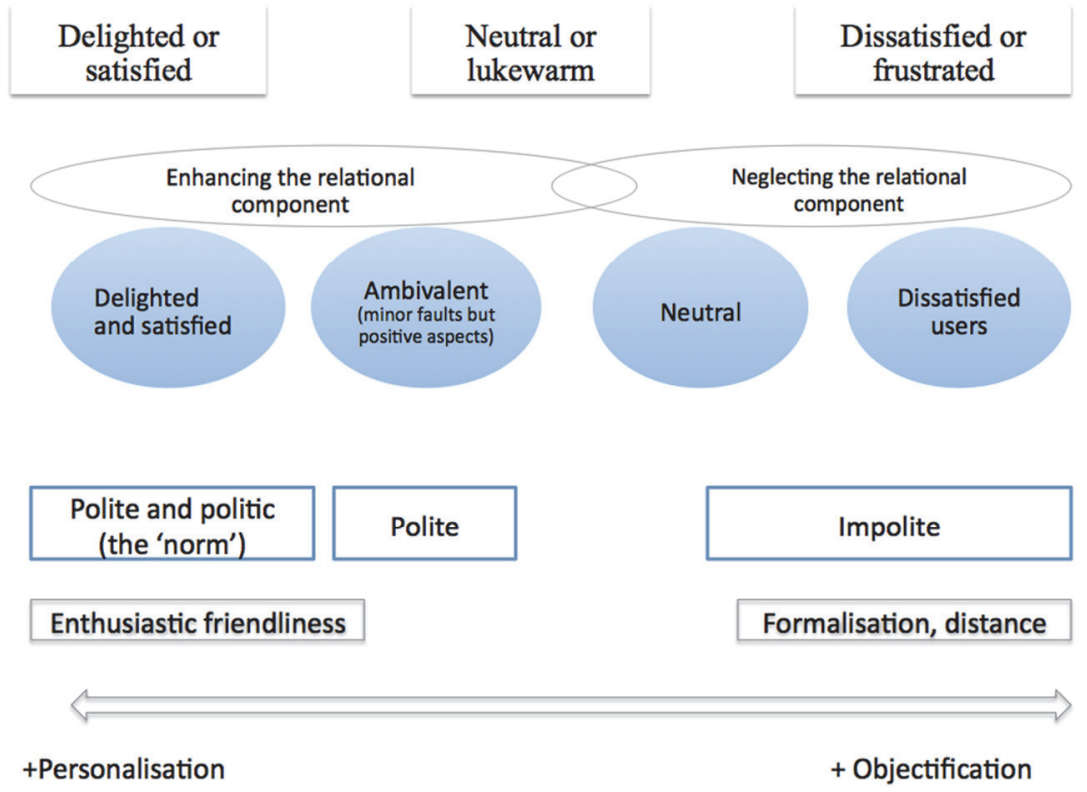

Figure 1. The relationship between polite/politic/impolite and satisfaction/dissatisfaction

The analysis developed in the previous section may bring about consequences in terms of what is considered to be polite, politic or impolite. While impoliteness/ rudeness may be present in reviews with a clearly negative bias, the boundaries between polite and politic are blurred, given that what is expected, the norm, is being polite in the form of effusive friendliness and closeness, echoing a letter structure that is more typical among friends than among almost strangers in an accommodation website. In turn, those that express some kind of fault but try to compensate for what is being said attempt to be polite with the host. They show concern about the relational component, despite minor faults. This form of politeness, however, is more related to routine formulae, formality and distance, a kind of depersonalisation or objectification, as it were. While delighted and satisfied users seek direct contact with the host as continuity of previous experience, (moderately) dissatisfied users seek the provision of information in a way that credibility does not become an issue, and therefore, their self-image is not jeopardised. Finally, very dissatisfied users prioritize in showing displays of frustration through messages that might be rude or offensive, but useful for their fellow travellers.

\section{Conclusions}

Despite the multicultural background that a globalised platform such as Airbnb involves, the reviews under examination present stable pragmalinguistic features that may be, in a way, conditioned by two constraints: first, as a genre, there is a stylistic pattern that is well-known by its users (experienced reviewers and travellers) that they want to follow. This is due to the fact that any deviation from the norm may have an impact on the users' role and identity in this community of practice (travellers who engage with peers). And second, the way the reviews are drafted greatly depends on the offline component of the experience, the relational work developed therein, and the importance given to faults, vis-à-vis the nature of host-guest relationship engaged. 
In a review system with a strong positivity bias such as Airbnb, the norm, being politic, is in fact being polite, and more specifically, it is being friendly, informal in tone and lively in the way the experience is recalled. Thus, while it is true that this review genre includes the type of descriptions found in other reviews (e.g. TripAdvisor), the social awareness of this particular CoP has an impact on the way information is drafted, the importance given to im/politeness and the tone chosen. This may bring about consequences not only to shape the pragmatic features of this relatively new platform in the sharing economy (vis-à-vis business-to-peer platforms such as TripAdvisor), but also to be able to identify the meanings that lie behind what is (and is not) said.

(C) María de la O Hernández-López cc) creative

https://creativecommons.org/licenses/by/4.0/

\section{REFERENCES}

Angouri, Jo \& Miriam A. Locher (2012).Theorising disagreement. Journal of Pragmatics, 44 (12), 1549-1553. https://doi.org/10.1016/j.pragma.2012.06.011.

Arundale, Robert (1999). An alternative model and ideology of communication for an alternative to politeness theory. Pragmatics, 9, 119-153.

Arundale, Robert (2006). Face as relational and interactional: a communication framework for research on face, facework and politeness. Journal of Politeness Research, 2, 193-217.

Barros García, María Jesús \& Marina Terkourafi (2014). First-order politeness in rapprochement and distancing cultures: Understandings and uses of politeness by Spanish native speakers from Spain and Spanish nonnative speakers from the U.S. Pragmatics, 24 (1), 1-34.

Botsman, Rachel \& Roo Rogers (2011). What's Mine is Yours: The Rise of Collaborative Consumption. New York: Harper Business.

Bridges, Judith \& Camilla Vásquez (2016). If Nearly all Airbnb Reviews are Positive, Does that Make them Meaningless? Current Issues in Tourism, 19, 1-19. https://doi.org/10.1080/ 13683500.2016 .1267113 .

Bulchand-Gidumal, Jacques \& Santiago Melián-González (2019). Why are ratings so high in the sharing economy? Evidence based on guest perspectives. Current Issues in Tourism, 22. https://doi.org/10.1080/13683500.2019.1602597.

Burt, Ronald (2000). The network structure of social capital. Research in Organizational Behavior, $22,345-423$.

Cansoy, Mehmet \& Juliet Schor (2016). Who gets to share in the sharing economy? Understanding patterns of participation and exchange on Airbnb. Retrieved from https://www.bc.edu/content/ dam/files/schools/cas_sites/sociology/pdf/SharingEconomy.pdf.

Chairunnisa, Sabrina \& A. S. Benedictus (2017). Analysis of Emoji and Emoticon Usage in Interpersonal Communication of Blackberry Messenger and WhatsApp Application. International Journal of Social Sciences and Management, 4 (2), 120-126.

Dayter, Daria \& Sofia Rüdiger (2014). Speak your Mind, but Watch your Mouth: Objectification Strategies in Negative References in CouchSurfing. In Bedijs, Kristina Held, Gudrun \& Maab, Christiane (eds.) Face Work and Social Media. Berlin: LIT Verlag, 193-212.

Dubé, Line, Anne Bourhis \& Réal Jacob (2005). The impact of structuring characteristics on the launching of virtual communities of practice. Journal of Organizational Change Management, 18 (2), 145-166. doi: 10.1108/09534810510589570. 
Eckert, Penelope \& Sally McConnell-Ginet (1992). Think practically and look locally: Language and gender as community-based practice. Annual Review of Anthropology, 21 (1), 461— 488.

Edwards, Derek (2000). Extreme case formulations: softeners, investment, and doing non-literal. Research on Language and Social Interaction, 33 (4), 347-373. https://doi.org/10.1207/ S15327973RLSI3304_01.

Ert Eyal, Aliza Fleischer \& Nathan Magen (2016). Trust and Reputation in the Sharing Economy: the Role of Personal Photos in Airbnb. Tourism Management, 55, 62-73.

Fraser, Bruce (1990). Perspectives on politeness. Journal of Pragmatics, 14, 219-236.

Garcés-Conejos Blitvich, Pilar (2010). A genre approach to the study of im-politeness. International Review of Pragmatics, 2, 46-94.

Garcés-Conejos Blitvich, Pilar \& Maria Sifianou (2019). Im/politeness in discursive pragmatics. Discursive politeness. Special issue of the Journal of Pragmatics: Recent developments in the field of pragmatics, guest edited by M. Haugh \& M. Terkourafi, 145: 91-101.

Guttentag, Daniel, Stephen Smith, Luke Potwarka \& Mark Havitz (2018). Why Tourists Choose Airbnb: A Motivation-Based Segmentation Study. Journal of Travel Research, 57(3), 342-359. https://doi.org/10.1177/0047287517696980.

Haugh, Michael (2019). The metapragmatics of consideration in (Australian and New Zealand) English. In: Ogiermann, E., Garcés-Conejos Blitvich, P. (eds.), From Speech Acts to Lay Understandings of Politeness. Cambridge University Press, Cambridge, 201-225.

Hernández-López, María de la $\mathrm{O}$ (2019). What makes a positive experience? Offline/online communication and rapport enhancement in Airbnb positive reviews. Pragmatics \& Society, 10 (2), 180-206. https://doi.org/10.1075/ps.16060.ohe.

Hernández-López, María de la O \& Lucía Fernández-Amaya (2019). What makes (im)politeness for travellers? Spanish tourists' perceptions at national and international hotels. Journal of Politeness Research, 15 (2), 195-222. Doi: https://doi.org/10.1515/pr-2016-0060.

Herring, Susan (2004). Computer-Mediated Discourse Analysis: An Approach to Researching Online Behavior. In S. Barab, R. Kling \& J.H. Gray (eds.) Designing for Virtual Communities in the Service Learning. Cambridge: Cambridge University Press, 338-76.

Ho, Victor (2017). Giving offense and making amends: How hotel management attempts to manage rapport with dissatisfied customers. Journal of Pragmatics, 109, 1-11.

Kamoen Naomi, Maria Mos \& Robbin Dekker (2015). A hotel that is not Bad isn't Good. The Effects of Valence Framing and Expectation in Online Reviews on Text, Reviewer and Product Appreciation. Journal of Pragmatics, 75, 28 - 43.

Levin, Irvin P., Sara K. Schnittjer \& Shannon L. Thee (1998). Information Framing Effects in Social and Personal Decisions. Journal of Experimental Social Psychology, 24 (6), 520-529.

Locher, Miriam A. (2006). Polite behavior within relational work: The discursive approach to politeness. Multilingua, 25, 249-267.

Locher, Miriam A. \& Watts, Richard J. (2005). Politeness theory and relational work. Journal of Politeness Research, 1 (1), 9-33.

Locher, Miriam A. \& Richard J. Watts (2008). Relational work and impoliteness: Negotiating norms of linguistic behaviour. In Dereck Bousfield and Miriam A. Locher (eds.) Impoliteness in Language. Studies in its interplay with Power in Theory and Practice. Berlin: Mouton de Gruyter, $77-99$.

Mills, Sara (2003). Gender and Politeness. Cambridge University Press, Cambridge. 
Pizam, Abraham (2014). Peer-to-peer travel: Blessing or blight? International Journal of Hospitality Management, 38, 118-119. Doi: 10.1016/j.ijhm.2014.02.013.

Rosen, Devan, Pascale R. Lafontaine \& Blake Hendrickson (2011). CouchSurfing: Belonging and Trust in a Globally Cooperative Online Social Network. New Media \& Society, 13 (6), 981—998.

Spencer-Oatey, Helen (2000). Culturally Speaking: Managing Rapport Through Talk Across Cultures ( $1^{\text {st }}$ ed.). London: Continuum.

Spencer-Oatey, Helen (2008). Culturally Speaking: Culture, Communication and Politeness Theory $\left(2^{\text {nd }}\right.$ ed.) London \& New York: Continuum.

Sthapit, Erose \& Jano Jiménez-Barreto (2019). You never know what you will get in an Airbnb: poor communication destroys value for guests. Current Issues in Tourism, 22 (19), 2315-2318. https://doi.org/10.1080/13683500.2018.1475469.

Torres, Edwin \& Sheryl Kline (2013). From customer satisfaction to customer delight. International Journal of Contemporary Hospitality Management, 25 (5), 642 - 659. https://doi.org/10.1108/ IJCHM-Dec-2011-0228.

Tussyadiah, Lis P. \& Pesonen, Juho (2015). Impacts of Peer-to-Peer Accommodation Use on Travel Patterns. Journal of Travel Research, 12, 1-19.

Vásquez, Camilla (2011). Complaints Online: The Case of TripAdvisor. Journal of Pragmatics, 43 (6), 1707-1717. https://doi.org/10.1016/j.pragma.2010.11.007.

Vásquez, Camilla (2014). 'Usually Not one to Complain but...': Constructing Identities in UserGenerated Online Reviews. In Seargeant, P. and Tagg, C. (eds.) The Language of Social Media: Identity and Community on the Internet. Basingstoke, UK: Palgrave Macmillan. https://doi.org/ 10.1057/9781137029317_4.

Virtanen, Tuija (2017). Adaptability in online consumer reviews: Exploring genre dynamics and interactional choices. Journal Pragmatics, 116, 77-90. https://doi.org/10.1016/ j.pragma.2017.03.009.

Watts, Richard J. (1989). Relevance and relational work: Linguistic politeness as politic behavior. Multilingua 8 (2-3), 131-166.

Wong, Siu-Iun \& Janet Salaff (1998). Network capital: emigration from Hong-Kong. The British Journal of Sociology, 49 (3), 358-374.

\section{Internet Resources}

Forbes (2018). Retrieved from: https://www.forbes.com/sites/hbsworkingknowledge/2018/02/27/ the-airbnb-effect-cheaper-rooms-for-travelers-less-revenue-for-hotels/\#26fbfc79d672.

Sundadarajan, Arun (2014, November 27) What Airbnb gets about culture that Uber doesn't. Harvard Business Review (Retrieved from https://hbr.org).

\section{Article history:}

Received: 28 September 2019

Revised: 19 October 2019

Accepted: 31 October 2019

\section{История статьи:}

Дата поступления в редакцию: 28 сентября 2019

Дата принятия к печати: 31октября 2019 


\section{Bionote:}

MARÍA DE LA O HERNÁNDEZ-LÓPEZ is a Lecturer Pablo de Olavide University. She holds a PhD in English Linguistics from Pablo de Olavide University and an MA in Applied Linguistics from Birkbeck College (London). She has worked at Greenwich University (London, UK), European Business School (London), Huelva University (Spain) and Pablo de Olavide University. Her research interests revolve around cross-cultural and intercultural communication in offline and online contexts, (im)politeness, rapport management, negotiation and interpersonal communication. She is currently working on online communication in peer-to-peer platforms, such as Airbnb and BlablaCar. Her latest research includes the co-edited volume Technology Mediated Service Encounters (John Benjamins, 2019).

Contact information: mariolahl@upo.es

\section{Сведения об авторе:}

МАРИЯ ДЕ ЛА О ЭРНАНДЕС-ЛОПЕС преподает в Университете им. Пабло де Олавиде. Она имеет докторскую степень в области английского языка и лингвистики (университет Пабло де Олавиде) и степень магистра прикладной лингвистики (Биркбек, Лондонский университет). Работала в Гринвичском университете (Лондон, Великобритания), Европейской школе бизнеса в Лондоне, Университете Уэльбы (Испания). Ее исследовательские интересы включают кросскультурную и межкультурную коммуникацию в офлайн и онлайн контекстах, (не)вежливость, управление взаимоотношениями, ведение переговоров и межличностное общение. В настоящее время она работает над онлайн-коммуникацией на платформах Airbnb и BlablaCar. Ее последняя публикация - Technology Mediated Service Encounters (John Benjamins, 2019).

Контактная информация: mariolahl@upo.es 